\title{
PENGARUH PELATIHAN DAN DISIPLIN KERJA TERHADAP KINERJA PEGAWAI PADA PERUM BULOG KANWIL SUMUT
}

\author{
KARNILA MANURUNG \\ Email Author: karnilamanurung16@gmail.com
}

\begin{abstract}
ABSTRAK
Pelatihan sangat penting untuk meningkatkan keterampiln pegawai, semakin terampil pegawai dalam bidangnya semakin baiklah hasil kerjanya. Selain itu displin juga harus ditegakkan demi kelancaran suatu pekerjaan. Pada penelitian ini seluruh populasi dijadikan sampel yaitu berjumlah 42 orang pegawai. Teknik analisis yang dipergunakan yaitu teknik analisis regresi linier berganda. Penelitian menemukan bahwa variabel pelatihan dan displin kerja secara parsial maupun memiliki pengaruh positif dan signifikan terhadap kinerja pegawai.
\end{abstract}

Kata kunci: pelatihan, displin kerja, kinerja

Training is essential to improve skills; the more skilled employees are in their fields, the better their work results. Also, discipline must be enforced for the smooth running of a job. In this study the entire population was sampled, amounting to 42 employees. The analysis technique used is multiple linier regression analysis. The result showed that the training and work discipline variables partially and simultaneously have a positive and significant effect on performance variables.

Keywords: training, work discipline, performance

Kata kunci: pelatihan, disiplin kerja, kinerja

\section{A. Pendahuluan}

Salah satu hal yang harus diperhatikan adalah keberhasilan berbagai kegiatan dalam suatu organisasi maupun perusahaan untuk dapat mencapai tujuan tidak hanya tergantung dalam suatu dana operasional, keunggulan teknologi yang telahada, sarana maupun prasarana yang ada, tetapi juga pada aspek tenaga kerja. Faktor tenaga kerja merupakan aspek yang penting untuk diperhatikan organisasi atau instansi supaya bisa bekerja lebih efektif, efisien, dan produktif. Sebab itu, manusia dapat dikatakansebagai faktor penentu. Dengan demikian, setiap perusahaan selalu berusaha dan berlomba-lomba untuk meningkatkan sumber daya manusia dalam perusahaannya. Ada banyak cara yang bisa dilakukan perusahaan atau organisasi untuk meningkatkan sumber daya manusianya diantaranya melaui pelatihan dan disiplin kerja.

Pelatihan sangat penting bagi karyawan untuk melakukan tugas yang diberikan kepada pegawai guna mencapai tujuan. Dengan mengadakan pelatihan memastikan pegawai yang terampil, terlatih dan terdidik serta pekerja yang berpikiran kritis. Pelatihan juga akan memungkinkan karyawan untuk mengembangkan 
diri mereka lebih baik dan lebih cepat, serta meningkatkan efisiensi kerja setelah mereka menerima pelatihan di bawah pengawasan para ahli.

Pelatihan adalah kegiatan yang dilakukan oleh manajemen personalia atau pengembangan sumber daya manusia, membutuhkan pelatihan karyawan secara terencana dan berkesinambungan agar pelatihan dapat dilaksanakan dengan benar. Pelatihan harus terlebih dahulu dilakukan dengan persetujuan organisasi atau perusahaan. Pelatihan yang dilakukan juga bertujuan untuk meningkatkan kemampuan bagi pegawai dan memperbaiki penguasaan berbagai keterampilan yang ada pada pegawai dalam waktu yang sebelumnya telah ditetapkan oleh organisasi atau perusahaan.

Setiap perusahaan selalu menginginkan hasil yang terbaik dari perusahaannya, dalam mencapai hal tersebut perusahaan tentunya memiliki peraturan dalam kegiatan perusahaannya. Salah satu peraturan yang selalu diterapkan oleh suatu perusahaan adalah tentang disiplin kerja. Disiplin kerja yang diterapkan dalam perusahaan biasanya bisa kehadiran, cara kerja, dan ketepatan waktu dalam menyelesaikan pekerjaannya, serta banyak hal lain yang menyangkut tentang disiplin kerja tergantung dari ketentuan setiap perusahaan. Disiplin kerja adalah peraturan yang dibuat oleh setiap perusahaan dengan bertujuan agar para pegawai dalam perusahaannya melakukan setiap pekerjaan dan segala kegiatan yang ada dalam perusahaan dilaksanakan dengan ketentuan yang telah disepakati. Dengan dibuatnya disiplin kerja tentunya akan dapat memaksimalkan kinerja pegawai dan dapat tercapainya tujuan dari perusahaan. Setiap perusahaan selalu berusaha dan melakukan berbagai cara atau metode agar kinerja dari pegawainya dapat terus meningkat.

Perum BULOG Kantor Wilayah Sumut adalahsuatu lembaga Badan Usaha Milik Negara (BUMN) yang berlokasi dijalan Gatot Subroto No. 180 Medan. Perum BULOG didirikan pada tanggal 10 Mei 1967. Dimana dalam menjalankan usahanya tentunya tidak terlepas dari pelatihan serta kedisiplinan yang mempengaruhi dari kinerja pegawai yang ada di lembaga itu.

Pelatihan yang dilakukan oleh Perum BULOG Kantor Wilayah Sumut pada saat ini merupakan sistem pelatihan yang berkelanjutan. Para pegawai selalu melakukan pelatihan baik dari awal sebelum para pegawai mulai aktif bekerja dalam perusahaan hingga saat para pegawai telah aktif bekerja, para pegawai tetap melakukan pelatihan dengan waktu dan pelatihan yang dibutuhkan pegawai sesuai dengan pekerjaan yang telah ditetapka oleh Perum BULOG Kantor Wilayah Sumut. Pelatihan yang dilakukan tidak hanya pelatihan dalam bidang pekerjaan, dalam pelatihan yang dilakukan oleh Perum BULOG Kantor Wilayah Sumut juga memberikan pelatihan berupa pelatihan fisik demi kesehatan para pegawai.

Dari penelitian yang saya lakukan masih ada beberapa pegawai yang telah melakukan pelatihan sebelumnya akan tetapi pegawai tersebut masih kurang mampu melakukan pekerjaannya dengan 
baik atau belum bisa melaksanakan sistem pekerjaan yang baru yang telah diberikan oleh Perum BULOG. Peniliti berpendapat agar pelatihan yang dilakukan seharusnya lebih teperinci dan dijelaskan lebih baik lagi agar para karyawan lebih memahami apa yang mereka kerjakan, bukan hanya mengikuti pelatihan saja akan tetapi tidak paham tentang pelatihan yang mereka ikuti.

Perum BULOG juga pastinya mempunyai disiplin kerja dalam perusahaannya, dalam penilitian yang dilakukan oleh peneliti masih ada beberapa pegawai yang tidakmengikuti peraturan tentang disiplin kerja yang telah ditetapkan oleh perusahan Perum BULOG. Menurut peneliti pelanggaran ini dilakukan karena kurang tegasnya dalam pemberian sanksi oleh perusahaan.

\section{B. Tinjauan pustaka}

Menurut penjelasan Sulistiyani (2018: 259), pelatihan biasanya diawali dengan pelatihan induksi, dan dalam proses ini karyawan akan dibekali dengan data dan pemahaman tentang ketenagakerjaan, institusi dan kehendak untuk menggapai suatu kekuatan tertentu. Pelatihan merupakan salah satu cara membantu karyawan memahami pengetahuan teknis pekerjaan, suapaya dapat meningkatkan kecakapan, keterampilan, dan sikap yang dibutuhkan perusahaan untuk mencapai tujuannya.

\begin{tabular}{lrrr}
\multicolumn{2}{c}{ Penyelenggaraan } & pelatihan & dan \\
pengembangan $\quad$ kerja & bertujuan & untuk \\
memperlengkapi, & mengintensifkan & dan
\end{tabular}

memperluas kapabilitas tenaga kerja untuk meningkatkan kapabilitas, produktivitas dan kesejahteraannya. Sulistiyani (2018:87), menjelaskan bahwa pelatihan jangan hanya merupakan upaya formal untuk meningkatkan kualitas pegawai, namun sebaiknya menjawab kebutuhan strategis atas kemampuan yang benarbenar dibutuhkan oleh organisasi publik.

Indikator adalah variabel-variabel dimana berguna untuk menunjukkan kepada penggunamengenai kondisi tertentu, sehingga dapat digunakan dalam mengukur perubahan yang terjadi. Indikator pelatihan menurut Anwar Prabu Mangkunegara (2014:62), antara lain: jenis pelatihan, tujuan pelatihan, materi, metode yang digunakan, kualifikasi peserta, kualifiasi pelatih, dan waktu.

Secara etimologis, disiplin berasal dari bahasa Inggris disciple yang artinya "pengikut" atau "penganut", “mengajar", "pelatihan". Disiplin adalah keadaan di mana anggota organisasi dapat mau mematuhi aturan yang ada dalam kondisi tertentu. Pada saat yang sama, pekerjaan adalah semua kegiatan manusia yang dikerjakan untuk mencapai sasaran yang sudah ditentukan. Ada beberapa faktor dalam disiplin kerja yang mempengaruhi karyawan atau sumber daya manusia perusahaan. Menurut Fadila Helmi terdapat dua faktor yang menjadi penyebab disiplin kerja yaitu faktor lingkungan dan faktor kepribadian (Hartatik, 2019: 197).

Dalam suatu organisasi, perlu adanya pembinaan kepada pegawai dimaksudkan bagi merintangi adanya perbuatan yang melanggar 
terhadap regulasi yang telah ditetapkan. Setiap pemimpin membutuhkan media untuk berkomunikasi dengan pegawai tentang perilaku mereka dan bagaimana memperbaikinya. Indikator disiplin kerja adalah variabel yang perlu diperhatikan, yang dapat membantu anda membuat penilaian yang ringkas, komprehensif dan seimbang terhadap kondisi atau aspek penting karyawan Anda.

Menurut Hasibuan (2016:194) indikator yang mempengaruhi tingkat kedisiplinan pegawaisuatu organisasimaupun instansi, diantaranya sebagai berikut: Tujuan dan kemampuan, teladanan pimpinan, Keadilan, Pengawasan melekat (waskat), Ketegasan, Hubungan kemanusiaan.

Kinerja pegawai adalah kebutuhan untuk memahami dan menginformasikan aspek-aspek tertentu dari kondisi untuk menentukan tingkat pencapaian pribadi berhubungan dengan visi yang diterapkan oleh instansi, dan untuk mengerti akibat positif dan negatif dari strategi operasi. Kinerja adalah produk yang didapat suatu instansi baik organisasi tersebut memiliki karakter profit oriented dan non profit oriented yang diproduksi dalam satu periode waktu (Fahmi, 2016:127).

Sedangkan Menurut Wirawan (dalam Triasmoko 2014:4), setiap indikator kinerja diukur berdasarkan kriteria standar tertentu. Kriteria standar tersebut adalah sebagai berikut : a. Kuantitatif (seberapa banyak). Ukuran Kuantitatif merupakan ukuran paling mudah disusun dan diukurnya, yaitu hanya dengan menghitung seberapa banyak unit keluaran kinerja harus dicapai dalam kurun waktu tertentu. b.Kualitatif (seberapa baik). Melukiskan seberapa baik atau seberapa lengkap hasil harus dicapai. c. Ketetapan Waktu Kriteria yang menentukan keterbatasan waktu untuk memproduksi suatu produk, membuat sesuatu atau melayani sesuatu. Penerapan pengukuran kinerja diperlukan sebagai standart apakah kinerja dari karyawan sesuai dengan sasaran yang diharapkan. Handoko \& Waluyo, (2017:33), indikator kinerja individu karyawan yaitu kualitas, kuantitas, dan ketepatan waktu.

Hubungan antara Pelatihan dan Disiplin Kerja dengan Kinerja Pegawai digambarkan dalam kerangka konseptual dibawah ini:

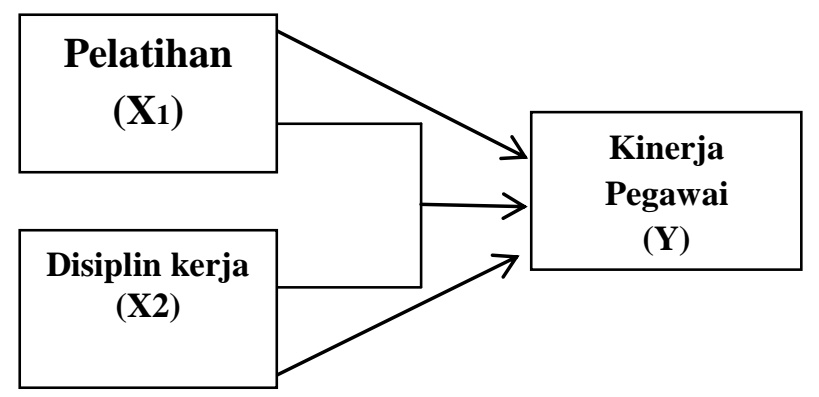

\section{Gambar 1. Kerangka Konseptual Penelitian}

Model tersebut diharapkan dapat menunjukan dan menguji pengaruh antara Pelatihan dan Disiplin Kerja dengan Kinerja Pegawai.

\section{Metode penelitian}

Populasi dalam penelitian ini merupakan seluruh karyawan Perum Bulog yang ada di Kanwil Sumatera Utara yang berjumlah 42 orang, dan seluruh populasi dijadikan sampel. Hipotesis 
diuji secara kuantitatif dengan menggunakan metode analisis regre linier berganda.

Tabel 1. Analisis Regresi Linier Berganda

\section{Hasil dan Pembahasan}

Uji validitas data dilaksanakan dengan menggunakan metode korelasi product moment (Pearson Correlation).Berdasarkan hasil pengolahan data diketahui bahwa tidak ada data yang tidak dikenal (missing), sehingga data penelitian ini merupakan data yang akurat dan dapat diteliti dengan menggunakan software Statistical Products and Service Solutions (SPSS) 24.0 .

Melaksanakan penyebaran kuesioner kepada 42 orang sampel penelitian yang ada untuk mengetahui valid tidaknya data penelitian. Hasil uji validitas dapat dilihat melalui pengolahan data dimana seluruh item pertanyaan dalam kuesioner valid, dikarenakan seluruh nilai corrected item total correlaction bernilai lebih besar atau sama dengan nilai $r_{\text {tabel }}$ adalah 0,312 .

Hasil uji reliabilitas kuesioner variabel pelatihan $\left(\mathrm{X}_{1}\right)$ dan disiplin kerja $\left(\mathrm{X}_{2}\right)$ dan variabel kinerja pegawai dinyatakan reliabel dan dapat digunakan untuk penelitian.

\section{Analisis Regresi Linier Berganda}

Hasil pengolahan data dengan menggunakan SPPS sebagai berikut:

\section{Coefficients $^{\mathrm{a}}$}

\begin{tabular}{|c|c|c|c|c|c|c|c|}
\hline \multirow[b]{2}{*}{ Model } & \multicolumn{2}{|c|}{$\begin{array}{l}\text { Unstandardiz } \\
\text { ed } \\
\text { Coefficients }\end{array}$} & \multirow{2}{*}{$\begin{array}{c}\begin{array}{c}\text { Standardize } \\
\mathrm{d} \\
\text { Coefficients }\end{array} \\
\text { Beta }\end{array}$} & \multirow[b]{2}{*}{$\mathrm{t}$} & \multirow[b]{2}{*}{ Sig } & \multicolumn{2}{|c|}{$\begin{array}{c}\text { Collinearity } \\
\text { Statistics }\end{array}$} \\
\hline & B & $\begin{array}{l}\text { Std. } \\
\text { Error }\end{array}$ & & & & $\begin{array}{c}\text { Toleran } \\
\text { ce }\end{array}$ & VIF \\
\hline $\begin{array}{l}1 \text { (Consta } \\
\text { nt) }\end{array}$ & $\begin{array}{r}9.59 \\
7\end{array}$ & 3.941 & & $\begin{array}{r}2.43 \\
5\end{array}$ & $\begin{array}{r}.02 \\
0\end{array}$ & & \\
\hline $\begin{array}{l}\text { Pelatiha } \\
\mathrm{n}\end{array}$ & .058 & .035 & .239 & $\begin{array}{r}2.64 \\
8 \\
\end{array}$ & $\begin{array}{r}.01 \\
7 \\
\end{array}$ & .831 & $\begin{array}{r}1.20 \\
4\end{array}$ \\
\hline Disiplin & .379 & .130 & .424 & $\begin{array}{r}2.92 \\
6\end{array}$ & $\begin{array}{r}.00 \\
6\end{array}$ & .831 & $\begin{array}{r}1.20 \\
4\end{array}$ \\
\hline
\end{tabular}

a. Dependent Variable: Kinerja Pegawai

Sumber: Data Penelitian Diolah

Maka hasil ini dapat diubah ke dalam bentuk persamaan matematis sebagai berikut:

$$
Y=9,597+0,058 X_{1}+\mathbf{0 , 3 7 9} X_{2}
$$

Adapun pengertian dari persamaan regresi di atas adalah:

a) Nilai Konstanta 9,597, yang menjelaskan bahwa tanpa variabel bebas (X) berupa Pelatihan dan Disiplin Kerja, Kinerja Pegawai Pada Perum BULOG Kantor Wilayah Sumatera Utara sebesar 9,597 satuan.

b) Variabel Pelatihan $\left(X_{1}\right)$

Koefisien sebesar 0,058 yang berarti jika terjadi penambahan pelatihan $\left(\mathrm{X}_{1}\right)$ dan variabel lain dianggap konstan, maka Kinerja Pegawai Pada Perum BULOG Kantor Wilayah Sumatera Utara juga akan ikut meningkat sebesar 0,058 satuan.

c) Variabel Disiplin Kerja $\left(\mathrm{X}_{2}\right)$

Koefisien 0,379 yang menjelaskan jika displin kerja $\left(\mathrm{X}_{2}\right)$ semakin baik dan variabel lain dianggap tidak berubah, maka Kinerja 
Pegawai Pada Perum BULOG Kantor Wilayah Sumatera Utara juga akan ikut meningkat sebesar 0,379 satuan.

\section{Uji Hipotesis}

a. Uji t

Dari pengolahan data yang dilakukan ditemukan nilai sig $<0,05(0,017<0,05)$, sehingga dapat dapat dikatakan bahwa pelatihan memberikan pengaruh yang signifikan terhadap kinerja pegawai Kanwil Perum Bulog Sumatera Utara. Disiplin kerja $\left(\mathrm{X}_{2}\right)$ juga menunjukkan nilai sig $<0,05(0,006<0,05)$.

\section{b. Uji F}

Hasil uji F untuk variabel Pelatihan dan disiplin kerja diperoleh nilai Fhitung sebesar 9,179 dengan nilai 0,000 . Oleh karena itu, dapat ditentukan bahwa pelatihan dan displin kerja secara simultan berpengaruh positif dan signifikan terhadap Kinerja Pegawai Pada Perum BULOG Kantor Wilayah Sumatera Utara.

\section{c. Koefisien Determinasi $\left(\mathbf{R}^{2}\right)$}

Koefisien determinasi $\left(\mathrm{R}^{2}\right)$ digunakan untuk membandingkan nilai potensi model dalam menjelaskan variabel dependen. Koefisien determinasi berkisar dari nol hingga satu $\left(0<\mathrm{R}^{2}<1\right)$. Jika nilai $\mathrm{R}^{2}$ besar (nilai hampir menjangkau angka 1) bisa dikatakan kalau variabel bebas $(\mathrm{X})$ memiliki dampak yang lebih besar terhadap variabel terikat (Y). Artinya model yang ada dapat menjelaskan kesanggupan variabel bebas dalam menjelaskan variabel terikat, demikian pula sebaliknya.
Diperoleh nilai $R_{\text {Square }}$ sebesar $0,620(62,00 \%)$ k, yang berarti persentase kontribusi variabel pelatihan dan disiplin kerja terhadap kinerja pegawai Perum Bulog adalah 62,00\%, dan $38,00 \%$ sisanya berasal dari luar penelitian. Faktor-faktor lain (berdasarkan kepemimpinan, gaji, lingkungan kerja, gaya kepemimpinan, dan kondisi nasional) dijelaskan atau dipengaruhi.

Hasil kerja seserorang diharapkan selesai tepat waktu dan dengan cara penuh biaya hemat, tentu saja tidak hanya dari sisi fisik seperti alat dan teknologi yang semakin mumpuni yang perlu mengalami transformasi akan tetapi gaya kepemimpinan. Pemimpin yang mampu menjalin komunikasi akan menjadi motor yang mampu membangkitkan percaya diri pegawai. Pergeseran pemikiran pemimpin yang ditakuti tidak akan menjamin keberhasilan sebuah instansi dalam mempertahankan kinerjanya. Pemimpin juga dengan gayangya harus mampu menyadarkan dan menyatukan persepsi pegawai tentang tujuan pelayanan instansi dalam kepentingan publik.

Displin kerja didasari pada itikat baik karyawan untuk memberi perhatian penuh terhadap tanggung jawabnya atau dengan kata lain kedisplinan seseorang menunjukkan ketertarikannnya terhadap suatu hal. Kedisplinan pegawai bersifat dua arah yaitu bagi pegawai sendiri dalam mengembangkan diri dan juga bagi perusahaan dalam meningkatkan produktivitas. Maka tidak ada alasan apabila ingin meningkat kinerja kedua hal ini sangat penting diperbaiki dalam pengelolaan dan penyelenggaraan aktivitas kerja instansi. 


\section{E. KESIMPULAN DAN SARAN}

Berdasarkan hasil yang ditemukan serta pembahasan yang sudah ada maka penulis menyimpulkannya sebagai berikut:

1. Pelatihan berpengaruh signifikan terhadap Kinerja pegawai pada Perum BULOG Kantor Wilayah Sumatera Utara, dijelaskan oleh nilai $\operatorname{sig}<0,05(0,017<0,05)$.

2. Ada pengaruh positif dan signifikan antara disiplin Kerja terhadap kinerja pegawai pada Perum BULOG Kantor Wilayah Sumatra Utara, dijelaskan dan nilai sig $<0,05$.

3. Pelatihan dan Disiplin Kerja secara simultan berpengaruh signifikan Terhadap Kinerja pegawai Perum BULOG Kantor Wilayah Sumatera Utara, dengan nilai $F_{\text {hitung variabel }}$ Pelatihan dan Disiplin Kerja adalah 9,179 dengan tingkat signifikan 0,001. Sedangkan, nilai $\mathrm{F}_{\text {tabel }}$ pada tingkat signifikan 95\% $(\alpha=$ 0,05) adalah 3,234 dimana $\left(F_{\text {hitung }}>F_{\text {tabel }}\right)$ sehingga $9,179>3,234$ dan nilai sig $<0,05$ $(0,001<0,05)$.

4. Nilai $R_{\text {Square }}$ yaitu 0,620 atau $62 \%$, artinya persentase kontribusi variabel penelitian berupa pelatihan dan disiplin kerja terhadap kinerja pegawai Perum Bulog adalah 62,00\%, dan $38,00 \%$ sisanya berasal dari luar penelitian.

Mengenai hasil penelitian, penulis memberikan saran kepada Perum BULOG Kantor Wilayah Sumatera Utara antara lain :

1. Pimpinan Perum BULOG Kantor Wilayah Sumut disarankan untuk dapat mempertahankan dan meningkatkan pelatihan bagi pegawai Melalui perbaikan terus menerus dalam penyelenggaraan pelatihan kerja sehingga dapat meningkatkan kinerja karyawan.

2. Disarankan kepada pimpinan Perum BULOG Kantor Wilayah Sumatera Utara agar lebih memperhatikan disiplin pegawai. Hal tersebut dapat dicapai dengan meningkatkan penerapan disiplin kerja, dengan disiplin yang baik akan memacu pegawai untuk berprestasi lebih baik lagi, kemudian pemimpin Perum BULOG Kantor Wilayah Sumatera Utara bisa menerapkan beberapa jenis disiplin kerja seperti: disiplin preventif, disiplin korektif,dan disiplin progresif.

\section{DAFTAR PUSTAKA}

1. Ambar T. Sulistiyani dan Rosidah. 2017, Manajemen Sumber Daya Manusia, Yogyakarta: Graha Ilmu.

2. Mangkunegara, AA. Anwar Prabu.2014. Manajemen Sumber Daya Manusia Perusahaan. Bandung: PT. Remaja Rosdakarya.

3. Hasibuan, M. S.P. 2014. Manajemen Sumber Daya Manusia. Jakarta: BUMI AKSARA.

4. Hartatik, Indah Puji. 2019. Buku Prakatis Mengembangkan SDM. Yogyakarta: Laksana.

5. Fahmi, Irham. 2016. Perilaku Organisasi. Bandung: Alfabeta.

6. Triasmoko, Denny. Moch. Djudi Mukzam, Gunawan Eko Nurtjahjono. 2014. 
Pengaruh Pelatihan Kerja Terhadap Kinerja Karyawan (Penelitian pada Karyawan PT Pos Indonesia (Persero)
Cabang Kota Kediri). Jurnal Administrasi Bisnis (JAB)|Vol. 12 No. 1 Juli 2014. 